\title{
The Activation, Expression and Function of Gelatinase A (MMP-2)
}

\author{
ゼラチナーゼA(MMP-2)の活性化、発現、およびその機能
}

\author{
Hewitt, Robert E.; Corcoran, Marta L. ; and Stetler-Stevenson, William G. \\ Extracellular Matrix Pathology Section, Laboratory of Pathology, Division of Clinical Sciences, National Cancer \\ Institute, Bethesda, MD 20892, USA, FAX: 1- 301-402-2628, E-mail: stetler1 @ helix.nih.gov
}

Key Words: angiogenesis, gelatinase A, invasion, metastasis, type-IV collagenase

\begin{abstract}
Gelatinase A is a member of the Matrix Metalloproteinase (MMP) family. These enzymes are usually secreted as latent pro-enzymes, are activated by proteolytic cleavage of an amino terminal domain, and are inhibited by tissue inhibitor of metalloproteinases (TIMPs). They are involved in extracellular matrix remodeling, both in normal processes of growth and development, and in pathological processes such as tumor invasion and metastasis. Gelatinase A has a number of distinctive characteristics, that suggest it may play a unique role in these processes. Unlike most MMPs it is constitutively expressed by many cells and has a ubiquitous tissue distribution. Another unique feature is that this protease is activated on the cell surface by the recently discovered membrane-type MMP (MTMMP). Expression of gelatinase A correlates with the aggressiveness of many tumors, which suggests that it may be a useful prognostic indicator, as well as a suitable target for anti-cancer therapies.
\end{abstract}

\section{A. Introduction}

Evidence for type-IV collagenase activity was first reported by Liotta et al. (1979), who found that an enzyme secreted by a metastatic murine tumor cleaved type-IV collagen, producing fragments consistent with a single cleavage site. The enzyme did not attack types I, II, III, and V collagen. Following purification, the enzyme was found to consist of two forms of approximately $68 \mathrm{kDa}$ and $62 \mathrm{kDa}$ daltons (Salo et al., 1983) representing latent and active forms, respectively. In subsequent studies, higher molecular weights have been reported, and the latent form is now identified as $72 \mathrm{kDa}$ (Collier et al., 1988). The type-IV collagenase described by Liotta et al. (1979) is now considered the second member of a growing family of proteases known as the matrix metalloproteinases (MMPs). The $72 \mathrm{kDa}$ type-IV collagenase is now referred to as MMP-2 or progelatinase A, to reflect its potent gelatinolytic activity.

\section{B. The MMP Family}

The matrix metalloproteinases (MMPs) are a family of zinc atom-dependent endopeptidases (Table I). They are usu-
要 約

ゼラチナーゼAは、マトリックスメタロプロテイナーゼ (MMP)ファミリーの一員である。このMMPファミリーは、普通 不活性なプロエンザイムとして分泌されて、 $\mathrm{N}$ 末端ドメインの 切断により活性化され、またTIMPsにより阻害される。それら は、細胞外マトリックスの再構築や、正常な成長と分化の過 程、および腫瘍の浸潤や転移のような病理学的過程に関わって いる。ゼラチナーゼAは、多くの点で他のMMPと異なった特徵 を持っているのでこれらの過程において特別な役割を担ってい ると推測されている。多くのMMPsと異なり、ゼラチナーゼAは 多くの細胞で構成的に発現されており、あらゆる組織に分布し ている。そのほかに特別な点としては、このプロテアーゼは最 近発見された細胞膜上に存在する膜型MMP(MT-MMP)により活 性化されるということである。この酵素の発現は、多くの腫瘍 の浸潤性に関係して扔り、そ机は癌治療に対する的確な標的と なると同時に、有用な予後の指標となると推測されている。

A.はじめに

IV型コラゲナーゼ活性はLiottaらによって最初に報告され た(1979)。彼らは転移性のネズミの癌が分泌するある酵素がIV 型コラーゲンを切断し、その分解産物は、1 箇所で切断された ものであることを見いだした。その酔素は、I、II、III、V型コ ラーゲンを分解しなかった。精製した後に、その酵素が、約 $68 \mathrm{kDa}$ と62kDaの 2 型から成り(Saloら、1983)、それぞれ潜在型 と活性型であることが分かった。その後の研究で、より高分子 量のものが報告され、その潜在型の分子量は現在では72kDa 同定された (Collier ら、1979)。現在ではマトリックスメタロプ ロテイナーゼ(MMPs)として知られるプロテアーゼファミリーは どんどん増えているが、Liottaらによって発見されたType IVב ラゲナーゼ (Liotta ら、1979) は、その2番目のものであると考え られている。72kDaのIV型コラゲナーゼは、強いゼラチン分解 活性をもつことから、MMP-2またはプロゼラチナーゼAと現在 呼ばれている。

B. MMP ファミリー

マトリックスメタロプロテイナーゼ(MMPs)は、带鉛原子 要求性エンドペプチダーゼのファミリーである(表 1)。それらは 
Table I. The matrix metalloproteinase family

\begin{tabular}{|c|c|c|}
\hline Enzyme & MMP & Substrate \\
\hline interstitial collagenase & MMP-1 & $\begin{array}{l}\text { collagens I, II, III, VII, VIII, X } \\
\text { gelatin, PG core protein }\end{array}$ \\
\hline neutrophil collagenase & MMP-8 & as above \\
\hline collagenase- 3 & MMP-13 & as above \\
\hline gelatinase $\mathrm{A}$ & MMP-2 & $\begin{array}{l}\text { gelatin, collagens IV, V, VII, X } \\
\text { elastin, fibronectin, PG coreprotein }\end{array}$ \\
\hline gelatinase $B$ & MMP-9 & $\begin{array}{c}\text { gelatin, collagens IV, V, elastin } \\
\text { PG core protein }\end{array}$ \\
\hline stromelysin-1 & MMP-3 & $\begin{array}{l}\text { PG core protein, fibronectin, laminin } \\
\text { collagen IV, } \mathrm{V}, \mathrm{IX}, \mathrm{X} \text {, elastin } \\
\text { pro-interstitial collagenase }\end{array}$ \\
\hline stromelysin-2 & MMP-10 & as above \\
\hline stromelysin-3 & MMP-11 & not determined \\
\hline matrilysin & MMP-7 & $\begin{array}{l}\text { fibronectin, laminin, gelatin } \\
\text { collagen-IV, PG core protein } \\
\text { pro-interstitial collagenase }\end{array}$ \\
\hline metalloelastase & MMP-12 & elastin \\
\hline membrane type & MT-MMP & gelatinase A \\
\hline
\end{tabular}

ally secreted as latent pro-enzymes, and are activated by proteolytic cleavage of an amino terminal domain. In addition, all are inhibited by tissue inhibitors of metalloproteinases (TIMPs). Recently however, some exceptions to these rules have been discovered: for example stromelysin- 3 has been found to be secreted in an activated form, and members of the MT-MMP subgroup have been found to be membrane-associated rather than secreted enzymes.

\section{Domain Structure}

All MMPs show sequence similarities, and share the following common domains (Fig. 1): i) the signal peptide domain
通常、不活性な酵素前駆体として分泌され、N末端ドメインの 切断により活性化される。それに加え、全ての酵素はTIMPによ り阻害される。しかしながら最近になって、これらの規則にい くつかの例外があることが見い出された。例えばストロメライ シン3は、活性型として分泌されることが発見され、またMTMMPサブグループに属するものは分泌酵素というよりはむしろ 膜結合型であることが見いだされている。

\section{C. ドメイン構造}

全てのMMPには1次構造に類似性がみられ、次のような共 通ドメインを持っている(1図): i)小胞体への翻訳生成物に向かわ

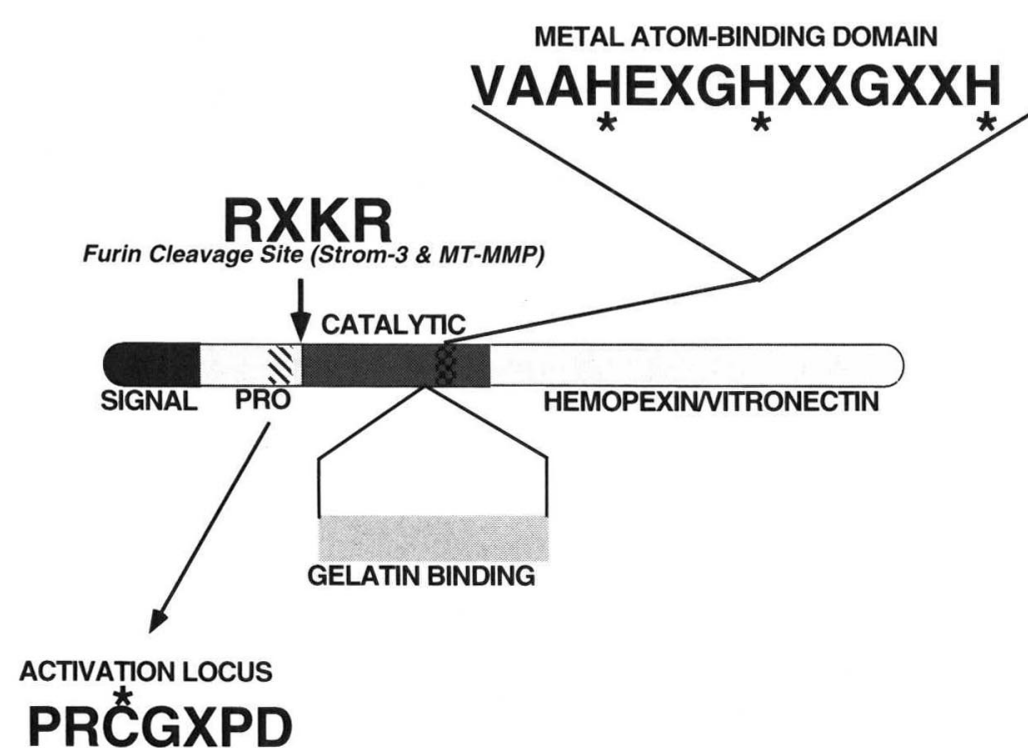

Fig. 1. Domain Structure of the Matrix Metalloproteinases. The matrix metalloproteinase (MMP) family is represented schematically to demonstrate the relative size and conservation of sequences between members of this group of proteases. Each member of the MMP family has at least four domains. These are: i) the signal peptide sequence that localizes the translation product to the endoplasmic reticulum; ii) the propeptide domain that is lost during enzyme activation; iii) the catalytic domain which contains the conserved sequence VAAHEXGHXXGXXH, in which the three histidine residue side chains serve as ligands to coordinate the zinc atom-binding; iv) the carboxy-terminal domain which has homology to hemopexin and vitronectin, is severly truncated in matrilysin, or contains a transmembrane domain in MTMMP. In addition there is a fifth domain that shows homology to the type II fibronectin repeats which bind gelatin and is found only in the gelatinase subgroup of the MMP family. 
which directs the translation product to the endoplasmic reticulum, ii) the pro-peptide domain which is removed during activation of the enzyme, iii) the catalytic domain which contains a thermolysin-like zinc-binding region, and iv) the carboxyl-terminal domain which has homology to both hemopexin and vitronectin (not found in matrilysin) (Kleiner and StetlerStevenson 1993). This carboxyl-terminal domain contains four 38 amino acid stretches that show a high degree of homology to regions of complement S-protein involved in binding to glycosaminoglycan and heparin. These sequences may explain the binding of collagenase and gelatinase A to heparin (Overall 1991).

The gelatinases also contain a fibronectin-like gelatinbinding domain inserted into the catalytic domain. This 175 amino acid region has been shown to be required for substrate specificity, in particular against type-IV collagen (Murphy et al., 1994). Gelatinase B is unlike gelatinase A in that it is glycosylated, and contains a 53 -amino acid sequence that shows some similarity with a segment of the $\alpha 2(\mathrm{~V})$ collagen chain.

\section{Enzyme Activation}

The latency of MMPs is thought to be maintained, at least partly, by a bond between the unpaired cysteine residue in a highly conserved sequence of the pro-peptide (PRCGXPDV), and the $\mathrm{Zn}$ atom at the active site. This Cys- $\mathrm{Zn}$ bond is thought to displace an $\mathrm{H}_{2} \mathrm{O}$ molecule that is needed for catalysis. Disruption of the Cys- $\mathrm{Zn}$ bond can be induced by organomercurials, metal ions, thiol reagents and oxidants. These are thought to destabilize the Cys- $\mathrm{Zn}$ interaction, either by interacting directly with the propeptide cysteine residue, or by interacting with adjacent residues to produce a conformational change that leads to destabilization of the bond. The bond is also disrupted by chaotropic agents ( $3 \mathrm{M} \mathrm{KI}$ and $3 \mathrm{M} \mathrm{NaSCN}$ ), hypochlorous acid and detergents (1-2\% SDS) which are thought to act by induction of conformational changes. When the Cys$\mathrm{Zn}$ bond is disrupted, the molecule assumes an "open" and active form. It then catalyses autolytic cleavages to irreversibly remove the propeptide domain. This model for activation is known as the "cysteine switch" hypothesis (Van Wart and Birkedal-Hansen, 1990).

\section{E. Enzyme Activity}

The gelatinases A and B degrade collagen types IV, V, and VII, as well as elastin, fibronectin and gelatin (denatured collagen) (Seltzer et al., 1989; Ray and Stetler-Stevenson, 1994). They cleave type IV collagen within the triple helical region, to generate the characteristic 1/4 amino terminal, and 3/ 4 carboxy terminal fragments.

Other members of the MMP family have different proteolytic activities: while the stromelysins also degrade type-IV
せるシグナルペプチドドメイン (ii)酵素が活性化されるときに除 かれるプロペプチドドメイン (iii)サーモリシン様の刺鉛結合部 位を含む酵素触媒ドメイン、そして(iv)へモペキシンおよびビト ロネクチンと相同性を持つC末端領域（マトリライシンにはみら れない) (Kleiner と Stetler-Stevenson、1993) このC末端ドメイ ンには、グリコサミノグリカンやへパリンとの結合に関与して いる補体のSタンパク質に高い相同性がみられる4つの38アミ, 酸残基が存在する。これらの配列は、コラゲナーゼやゼラチ ナーゼAのヘパリンに対する結合性を説明するかも知れない (Overall 1991)。

またゼラチナーゼの触媒領域にはフィブロネクチン様ゼラ チン結合領域が入り込んでいる。この175アミノ酸残基からなる 領域が、その基質特異性、特にIV型コラーゲンに対して必須で あるとみられている (Murphy ら、1994)。ゼラチナーゼBは、ゼ

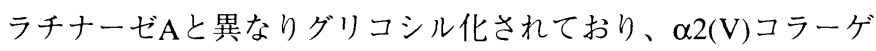
ン鎖のある部分と相同性を示す53アミノ酸配列が存在してい る。

\section{D. 酵素の活性化}

MMPsの活性潜在状態は、少なくとも部分的には非常によ く配列が保たれているプロペプチド (PRCGXPDV) 中にある遊離 のシステイン残基と、活性部位のZn原子の間の結合によるもの と考えられている。このCys-Zn結合は、 $\mathrm{H}_{2} \mathrm{O}$ 分子と置き換わ り、それが活性発現に必要であると考えられている。Cys-Zn結 合の開裂は、有機水銀化合物、金属イオン、チオール試薬、強 酸化物質によって引き起こすことができる。これらは直接プロ ペプチドのシステイン残基と作用することによって、あるいは 近接した残基に作用し立体構造の変化を引き起こして結合の不 安定化を導くことにより、Cys-Zn間の相互作用を不安定化する ためであると考えられている。その結合はまた、立体構造の変 化を引き起こすと考えられているカオトロピック試薬 (3M KI と $3 \mathrm{M} \mathrm{NaSCN})$ 、次亜塩素酸や界面活性郕 (1-2\% SDS) によっても こわされる。Cys-Zn結合が開裂すると、分子は開かれて活性型 となる。その後に自己分解によりプロペプチドドメインを恒久 的に取り除く。この活性化モデルは、「システインスイッチ」 仮説として知られている(Van Wart と Birkedal - Hansen、1990)。

\section{E. 酵素活性}

ゼラチナーゼA及びBは、IV、V及びVII型コラーゲンやエ ラスチン、フィブロネクチン、ゼラチン (変性したコラーゲン) を分解する (Seltzerら、1989；RayとStetler - Stevenson、1994)。 それらは、IV型コラーゲンの3重らせん部位を切断し、アミノ末 端側の $1 / 4$ とC末端側の $3 / 4$ ののを生成させる。

MMPファミリーの他のものは、異なった蛋白質分解活性を 持つ: ストロメライシンもまた、IV型コラーゲンを分解するが、 
a) Gelatinase A promoter

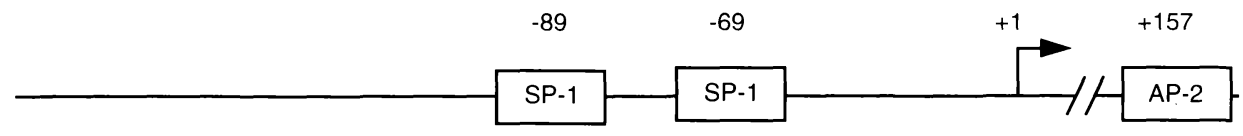

b) Generalized MMP promoter

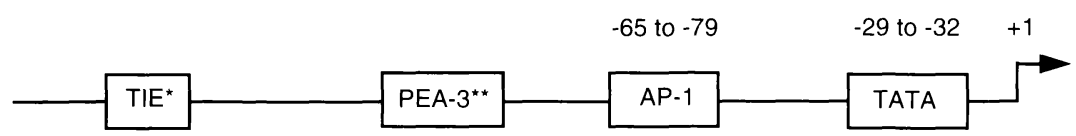

Fig. 2. Comparison of the promoters of gelatinase A and other MMPs. TATA boxes, AP-1, AP-2 sites, PEA-3 elements and TGF- $\beta$ inhibitory elements (TIE) are indicated. Transcription initiation sites are indicated by bent arrows. Nucleotide positions are shown above each element. * TIE-like sequences are present for gelatinase B (-474), collagenase (-245) and matrilysin (-475, -500, and -820). ** PEA-3 elements are present for collagenase (-89), stromelysin-I (-208, -216), stromelysin-II (-181) and matrilysin $(-475,-500$, and -820$)$, but not for gelatinase B.

collagen, they cut in the non-helical regions, and in addition they degrade laminin, fibronectin and proteoglycans. The interstitial collagenases do not degrade type-IV collagen, but instead degrade collagen types I, II, III, VII and X (BirkedalHansen et al., 1993). MT-MMP activates gelatinase A by proteolytic removal of a portion of the amino-terminal domain.

\section{F. Multi-level Regulation of Gelatinase A}

Synthesis of pro-gelatinase A could be regulated at both transcriptional and post-transcriptional levels. Further regulation occurs at the level of activation of the pro-enzyme. Following activation, enzyme activity is then down-regulated by tissue inhibitors of metalloproteinases (TIMPs).

\section{F-1. Transcriptional Regulation}

Unlike other MMPs, pro-gelatinase A is constitutively expressed by many cell types, and its transcription is not readily induced by agents such as TPA or IL-1 which have been shown to induce transcriptional activation of other MMPs (i.e. interstitial collagenase and gelatinase B) by as much as 100 fold (Brown et al., 1990). Inducers of MMP expression are generally thought to act at the transcriptional level, and analysis of promoter regions shows marked differences between gelatinase A and other MMPs (Fig. 2) (Matrisian 1994). Like most housekeeping genes, the promoter region of gelatinase A lacks a TATA box (Huhtala et al., 1990). By contrast, a TATA box is present in the promoters of most MMPs including gelatinase B, interstitial collagenase, stromelysins- 1 and -2 , and matrilysin (Matrisian 1994). Another striking difference between gelatinase A and other MMPs, is that its promoter lacks an AP1 site or TPA response element (TRE) (Frisch et al., 1990; Overall et al., 1991). Consistent with this, TPA fails to induce gelatinase A expression in normal human fibroblasts, while it
非らせん部位を切断し、その上ラミニン、フィブロネクチン、 そしてプロテオグリカンも分解する。間質コラゲナーゼはIV型 コラーゲンを分解しないが、代わりにI、II、III、VIIそしてX型コ ラーゲンを分解する (Birkedal-Hansenら、1993)。MT-MMPは、 ゼラチナーゼAをアミノ末端ドメインの一部をタンパク分解除 去することにより活性化させる。

F. ゼラチナーゼAの多レベル調節

プロゼラチナーゼAの合成は、転写量と転写後の発現量に より調節されているらしい。さらに、プロエンザイムの活性化 の度合いによっても調節される。活性化の後には、酵素活性は 組織性メタロプロテイナーゼ阻害物質 (TIMPs)による阻害に よっても調節されている。

\section{F-1. 転写調節}

他のMMPsと異なりプロゼラチナーゼAは様々な細胞で構 成的に発現されており、その他のMMPs（例えば間質コラゲ ナーゼやゼラチナーゼB）にみられるようにTPAやIL-1により転 写活性が100倍以上誘導されることはない (Brownら、1990)。 MMPの発現を誘導するものは、一般に転写に対して働くと考え られており、プロモーター領域の分析ではゼラチナーゼAとほ かのMMPsの間には相異がみられてい(2図) (Matrisian 1994)。

多くのハウスキーピングジーンのように、ゼラチナーゼA のプロモーター領域にはTATAボックスが欠如している (Huhtala ら、1990)。対照的に、TATAボックスはゼラチナーゼB、間質 コラゲナーゼ、ストロメライシン-1、2、そしてマトリライシン など多くのMMPsのプロモーター領域に存在している (Matrisian 1994)。そのほかのゼラチナーゼAと他のMMPsの違いのなかで 驚くべきことには、そのプロモー夕領域にはAP-1サイトもしく はTPA反応性領域 (TRE) が欠如していることである (Frisch ら、 1990 ; Overallら、1991)。このことは、TPAはヒト正常線維芽細 胞においてゼラチナーゼAの発現を誘導しないが、コラゲナー 
does so for collagenase and stromelysin (Collier et al., 1988; Overall et al., 1990). The gelatinase A promoter also lacks PEA-3 transcription elements, that are present for interstitial collagenase, stromelysin- 1 and -2 , and matrilysin (Matrisian, 1994). PEA-3 elements are recognized by transcription factors of the c-ets family. They are thought to function in combination with AP-1 elements, and to be responsible for growth factor and oncogene inducibility of interstitial collagenase and stromelysin. Also unlike other MMPs, the gelatinase A promoter lacks an upstream TGF- $\beta$ inhibitory element (TIE) (Matrisian, 1994). Once again, consistent with these findings, TGF- $\beta 1$ fails to inhibit gelatinase A expression, and in fact has the opposite effect of increasing gelatinase A mRNA levels and transcription rates in a range of cell types (Brown et al., 1990; Overall et al., 1991). As would be expected, TGF- $\beta 1$ inhibits expression of interstitial collagenase and stromelysin genes (Kerr et al., 1990).

TGF- $\beta 1$ is thought to be an important regulator in development and repair of tissues. It acts in a concerted manner to increase the formation of connective tissue, in general, by increasing the synthesis of matrix proteins and decreasing the synthesis of proteases. The fact that TGF- $\beta 1$ induces gelatinase A synthesis therefore seems paradoxical. Overall et al., (1991) have argued that this indicates a key role for gelatinase A, and suggest that the enzyme may facilitate remodeling of the extracellular matrix, by removing abnormal and unfolded collagen that would retard the process. Further evidence for a key role for gelatinase A activity comes from the fact that while TGF- $\beta 1$ increases TIMP-1 expression, it decreases the expression of TIMP-2 (Stetler-Stevenson et al., 1990). Since TIMP-2 complexes specifically with pro-gelatinase A, the net effect of TGF$\beta 1$ may therefore be to induce production of uncomplexed gelatinase A, which would be a highly active but short-lived enzyme (as discussed below).

\section{F-2. Post-Transcriptional Regulation}

There is evidence for post-transcriptional regulation of gelatinase A expression (Overall et al., 1991). In human fibroblasts treated with TGF- $\beta 1$, the half-life of gelatinase A mRNA increased from 46 to $150 \mathrm{~h}$, but the stability of TIMP-1 mRNA was unaffected (Overall et al., 1991).

\section{F-3. Regulation of Pro-enzyme Activation}

For other MMPs, like interstitial collagenase, stromelysins 1 and 2 , and gelatinase $\mathrm{B}$, the evidence suggests that plasmin and urokinase are the physiological activators (Mignatti and Rifkin, 1993). Pro-enzyme forms of interstitial collagenase, neutrophil collagenase, and stromelysins- 1 and -2 all have propeptide sequences that are cleavable by plasmin. Once activated, stromelysin- 1 can potentiate interstitial collagenase, and activate pro-gelatinase B (Murphy et al., 1994). Other likely examples of MMP activation by MMPs include matrilysin mediated activation of prostromelysin- 1 and
ゼやストロメライシンは誘導するということと一致する (Collier ら、1988; Overall ら、1990)。ゼラチナーゼAのプロモーターは また、PEA-3転写因子も欠損しているが、それは間質コラゲ ナーゼ、ストロメライシン1と2、そしてマトリライシンには存 在している (Matrisian、1994)。PEA-3因子はc-etsファミリーに属 する転写調節因子により認識される。それらはAP-1因子と共同 して機能しており、成長因子やオンコジーンに対し間質コラゲ ナーゼやストロメライシンが誘導させるのに㗢いていると考え られている。また他のMMPsと異なり、ゼラチナーゼAのプロ モーター領域には、上流のTGF- $\beta$ 阻害領域 (TIE) が欠如してい る (Matrisian、1994)。この場合もまた、TGF-ßはゼラチナーゼ Aの発現を阻害することはできず、事実多くの細胞において、 ゼラチナーゼAのmRNA発現量の増加と転写速度の増加すると いう逆の効果をもたらしている (Brown ら、1990; Overall ら、 1991)。そして期待どうり、TGF-ß1は、間質コラゲナーゼや、 ストロメライシンの遺伝子発現を阻害する (Kerr ら、1990)。

TGF- $\beta 1$ 1 発生や組織修復時における重要な調節因子で あると考えられている。TGF- 31 1、一般的にいえば、マト リックスタンパク質合成の増加とプロテアーゼ合成の減少させ ることによって結合組織形成の増加に協調的に作用している。 TGF ß-1がゼラチナーゼAの合成を誘導するという事実は、それ ゆえ矛盾にしているように思われる。Overallら (1991)は、これ はゼラチナーゼAの主要な役割を示していると主張しており、 この酵素が細胞外マトリックスの組織修復において、組織修復 過程を遅れさせる、異常またはへリックスを形成していないコ ラーゲンを取り除くことにより、修復を促進させているらしい と推測している。ゼラチナーゼAの活性が重要な役割を担って

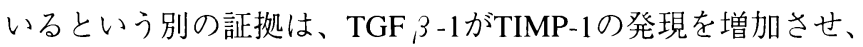
TIMP-2の発現を減少させるという事実である (Stetler-Stevenson ら、1990)。TIMP-2は特異的にプロゼラチナーゼAと複合体を作 るため、TGF 及-1の正味の効果はそれゆえ複合体を形成してい ないゼラチナーゼAの産生の誘導であるが、そのような酵素は 寿命は短いが高い活性を持つ(後で議論するが)。

\section{F-2.転写後の調節}

ゼラチナーゼAの発現が転写後に調節されているという証

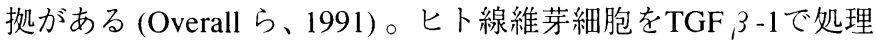
すると、ゼラチナーゼAのmRNAの半減期は46時間から150時間 に増加したが、TIMP-1のmRNAの安定性には影響を受けなかっ た(Overall ら、1991)。

\section{F-3.酵素前駆体活性化の調節}

間質コラゲナーゼや、ストロメライシン1と2、そしてゼラ チナーゼBのような他のMMPsに関しては、プラスミンやウロキ ナーゼが生理的な活性化剂であると推測されている (Mignatti と Rifkin、1993)。間質コラゲナーゼや好中球コラゲナーゼ、スト ロメライシン 1 や 2 の酵素前駆体はすべて、プロペプチド配列を 持っているが、それはプラスミンにより切断することができ る。ストロメライシン1はひとたび活性化されれば、間質コラ ゲナーゼの活性をさらに強めることができ、そしてプロゼラチ ナーゼBを活性化することができる (Murphyら、1994)。そのほ かの同様なMMPsによるMMPの活性化の例としては、マトリラ イシンが、プロストロメライシン-1やプロゼラチナーゼBの活性 
progelatinase $\mathrm{B}$, and gelatinase $\mathrm{A}$ mediated activation of progelatinase B (Fridman et al., 1995). Although some studies using crude enzyme preparations did suggest that progelatinase A might be activated by plasmin (Keski-Oja et al., 1992; Salo et al., 1982), others have demonstrated cell-mediated activation of gelatinase $\mathrm{A}$ in the presence of serine protease inhibitors (Atkinson et al., 1992, Brown et al., 1990).

Unlike other MMPs, the activation of gelatinase A has been shown to occur on the cell surface. A membrane-associated specific activator of gelatinase $\mathrm{A}$ can be induced in a range of cell types by agents such as concanavalin A, cytochalasin D, phorbol esters, and transforming growth factor $\beta 1$ (Brown et al., 1993, Overall and Sodek 1990, Ward et al., 1991). Activation of pro-gelatinase A, by membrane preparations from cells treated with these agents, is blocked by metalloproteinase inhibitors, including 1,10-phenanthroline, synthetic peptide inhibitors, and the TIMPs (Murphy et al., 1994, Ward et al., 1991). This membrane-dependent activation of pro-gelatinase A results in initial cleavage of the pro-peptide at Asn37-Leu38 to give a $64 \mathrm{kDa}$ intermediate, followed by cleavage at Asn80Phe81 to give the final $62 \mathrm{kDa}$ active enzyme (Strongin et al., 1993). Cleavage at Asn80-Phe81 also occurs during autoactivation in the presence of an organomercurial (StetlerStevenson et al., 1989), and it has been suggested that the association of gelatinase A with membrane component(s) may initiate autoactivation of the enzyme (Strongin et al., 1993; Bergmann et al., 1995).

It has recently been shown that "membrane type" MMP (MT-MMP), may represent the cell membrane-associated activator of pro-gelatinase A (Sato et al., 1994). There is evidence that MT-MMP acts as a receptor for TIMP-2, and can complex with pro-gelatinase A because of the interaction that occurs between TIMP-2 and the carboxyl-terminus of pro-gelatinase A. Formation of this complex may lead to subsequent activation of pro-gelatinase A (Strongin et al., 1995). MT-MMP has a transmembrane (TM) domain, and truncation of this domain abolishes the gelatinase A activation function of MT-MMP. This suggests that the TM domain may be important in orienting MT-MMP on the cell surface, so that it can interact effectively with gelatinase A (Cao et al., 1995). Interestingly, some tumor cell lines have been shown to bind pro-gelatinase A without activating the enzyme (Emonard et al., 1992), so that binding and activation of progelatinase $\mathrm{A}$ are dissociable processes. This evidence suggests that progelatinase A activation depends on cooperative interactions between a number of different molecules, including MT-MMP. The role of TIMP-2 in these interactions is a controversial matter, and while some investigators believe that TIMP-2 inhibits the cell surface activation of progelatinase $\mathrm{A}$, others believe it may enhance activation through formation of progelatinase A-TIMP-2 complex which facilitates binding of the progelatinase $A$ to the cell surface.
化をもたらしたり、ゼラチナーゼAが、プロゼラチナーゼBの活 性化をもたらすといったようなことがある(Fridman ら、1995)。 粗酵素標品を用いたものではあるがいくつかの研究から、プロ ゼラチナーゼAがプラスミンによって活性化されるということ が推測されている (Keski - Oja ら、1992、Saloら、1982)が、一方 ではセリンプロテアーゼインヒビターの存在下で細胞を介した ゼラチナーゼAの活性化が見られたというような報告がある (Atkinson ら、1992、Brown ら、1990)。

他のMMPs と異なり、ゼラチナーゼAの活性化は細胞の表 面で起こることが観察されている。ゼラチナーゼAの細胞膜結 合型特異的活性化物質は、さまざまな細胞でコンカナバリン $\mathrm{A}$ やサイトカラシンD、フォルボールエステル、TGF アー1のような 試真によって誘導させることができる (Brown ら、1993、Overall と Sodek 1990、Wardら、1991)。これら試薬で処理した細胞か ら調製した細胞膜によるプロゼラチナーゼAの活性化は、1,10フェナンスロリン、合成ペプチド性阻害剤、そしてTIMPsなど のメタロプロテイナーゼ阻害物質により阻止された (Murphy ら、 1994、Ward ら、1991)。このゼラチナーゼAの細胞膜による活性 化では、最初にAsn37-Leu38の間でプロペプチドが切断されて 64kDaの中間体ができ、ついでAsn80-Phe81の間が切断されて最 終生成物の62kDaの活性型が生成される (Strongin ら、1993)。ま た、Asn80-Phe81の間の切断は有機水銀化合物の存在下における 自己活性化の最中においても起こっており (Stetler-Stevenson ら、 1989)、それは膜を構成成分とゼラチナーゼAとの結合が、酵素 の自己活性化のきっかけになるかもしれないことを示している (Strongin ら、1993; Bergman ら、1995)。

最近見つかった膜型MMP (MT-MMP) は、プロゼラチナー ゼAの細胞膜結合型活性化物質として見いだされた (Satoら、 1994)。MT-MMPがTIMP-2の受容体として働いていて、TIMP-2 がプロゼラチナーゼAのC末端と結合するためにMT-MMPは、 プロゼラチナーゼ $\mathrm{A}$ 複合体を形成できるのだという証拠が見 いだされている。この複合体の形成が、結果としてプロゼラチ ナーゼAを活性化に導いているのだろう (Strongin ら、1995)。 MT-MMPは膜貫通 (TM) 領域を持つが、この領域を欠除させる とMT-MMPはゼラチナーゼAを活性化する機能を失う。このこ とは、TM領域がMT-MMPとゼラチナーゼAが効果的に相互作用 するように細胞表面にMT-MMPを配向させるのに重要な役割を 果たしていることを推測させる (Cao ら、1995)。興味深いこと に、数種の腫瘍細胞株において、プロゼラチナーゼ $\mathrm{A}$ と MTMMPの結合と活性化は別々の過程であるかのように、プロゼラ チナーゼAが結合するのに酵素の活性化が起こらないことが見 られた (Emonard ら、1992)。この結果から、プロゼラチナーゼ Aの活性化はMT-MMPを含む多数の異なった分子間での協同の 相互作用のためであると推測される。これら相互作用における TIMP-2の役割は、論争の的となって抢り、ある研究者はプロゼ ラチナーゼAの細胞表面に扔ける活性化をTIMP-2が阻害してい ると信じているのに対して、一方ではプロゼラチナーゼATIMP-2複合体が形成されることによって細胞表面に対するプロ ゼラチナーゼAの結合が容易になり活性化が高まっているのか もしれないと信じている研究者もいる。 
Like all MMPs, MT-MMP is first synthesized as an inactive proenzyme. The amino acid sequence (RXKR) close to the site of MT-MMP pro-peptide cleavage, suggests that proMT-MMP would be an excellent substrate for serine proteases. It is therefore possible that proMT-MMP is activated by enzymes like plasmin and its activator urokinase-type plasminogen activator (u-PA), which itself has a plasma membrane-associated receptor (Strongin et al., 1995). Another possibility is that proMT-MMP, like prostromelysin-3, is activated intracellularly by the golgi-associated protease, furin (Pei and Weiss 1995), as both MMPs contain the enzyme's recognition motif (RXKR) upstream of the catalytic domain.

Evidence that progelatinase $\mathrm{A}$ activation depends on a number of factors, comes from recent studies on the effects of the lectin, concanavalin A (con A). Yu et al. (1995) have shown that con A stimulates activation of progelatinase A by inducing the transcription of proMT-MMP mRNA, and also by an as yet undefined transcription-independent mechanism that requires protein synthesis. The authors also suggest that $\operatorname{con} \mathrm{A}$, which is known to stimulate cell membrane receptor aggregation and endocytosis, may serve to physically concentrate MTMMP and progelatinase A at the cell surface (Yu et al., 1995). They propose that this may lead to increased interaction between the two molecules, as well as enhanced autoactivation of progelatinase A. As lectins have been isolated from a number of transformed cell lines and are produced by various microorganisms, it is possible that they play a role in activating progelatinase A in a range of disease processes (Overall 1991).

A recent study indicates that gelatinase $A$ is capable of activating pro-gelatinase B (Fridman et al., 1995), so that both gelatinases may be activated at the same time, in close proximity to the cell surface. The fact that processing and activation of gelatinase A appears to be restricted to the cell surface is likely to have important implications in vivo, as it would allow migrating and invading cells to focus gelatinase $\mathrm{A}$ activity to the immediately adjacent areas of extracellular matrix (Brown et al., 1993). Consistent with this idea, active gelatinase A has been shown to be localized to the invadopodia of malignant cells (Monsky et al., 1993).

\section{F-4. Regulation of Activity by TIMPs}

MMPs are all inhibited by tight-binding protein inhibitors called TIMPs (Stetler-Stevenson 1990). Three human TIMPs have now been cloned and sequenced. Predicted MWs of the core proteins using cDNA sequence data for TIMP-1, -2 and -3 , are all approximately $21 \mathrm{kDa}$. However, as TIMP- 1 and TIMP-3 are glycosylated they run on SDS-PAGE as proteins of $28 \mathrm{kDa}$ and $24 \mathrm{kDa}$ respectively (Wilde et al., 1994). TIMP-2 is not glycosylated, and has a reported MW of $21-24 \mathrm{kDa}$ (Stetler-Stevenson et al., 1989). The TIMPs all form high affinity, non-covalent complexes with active forms of all MMPs. These complexes have a $1: 1$ stoichiometry. In addition, com-
すべてのMMPsと同様に、MT-MMPは初め不活性なプロエ ンザイムとして合成される。MT-MMPのプロペプチド切断部位 に近いアミノ酸配列 (RXKR) は、プロMT-MMPがセリンプロテ アーゼの良い基質であることを示している。それゅえにプロ MT-MMPが、プラスミンや、その活性化物質でありそれ自身が 形質膜受容体を持つウロキナーゼ型プラスミノーゲンアクチ ベーター(u-PA)のような酵素により活性化されることが可能で ある(Strongin ら、1995)。そのほか、プロストロメライシン-3 と同様にプロMT-MMPは、触媒領域の上流に酵素認識モチーフ (RXKR) が存在するため、フリンのようなゴルジに存在するプ ロテアーゼによって細胞内で活性化される可能性もある。

プロゼラチナーゼAの活性化が多くの因子によるものであ るという証拠は、レクチンであるコンカナバリンA (Con A) の 効果についての最近の研究によってもたらされた。Yuら (1995) は、Con AはプロMT-MMP mRNAの転写を促進およびまだ解明 されていないが転写とは無関係な、しかしタンパク質合成を必 要とする機構によりプロゼラチナーゼAの活性化を促進するこ とを見いだした。著者らはまた、細胞膜受容体を集合させエン ドサイトーシスを促進させるものとして知られるCon Aが細胞表 面においてMT-MMPとプロゼラチナーゼAを生理的に集めるこ とに寄与しているのかもしれないと推測している(Yuら、1995) 彼らは、これが二つの分子間の相互作用を増加させ、それと 同時にプロゼラチナーゼAの自己分解を高めるだろうと提言し ている。レクチンは多くの変異した細胞株から分離されたり、 様々な微生物によって産生されているので、疾病のある場面で プロゼラチナーゼAの活性化の役割をはたしている可能性があ る(Overall 1991)。

最近の研究で、ゼラチナーゼAがプロゼラチナーゼBを活性 化できることが示されたので、細胞表面の近接したところでゼ ラチナーゼAとBの双方が同時に活性化されると推測される。ゼ ラチナーゼAのプロセシングと活性化がみられるのが細胞表面 に限られるという事実は、in vivoに抄いて移動している細胞や 浸潤している細胞がゼラチナーゼAの活性化を細胞外マトリッ クスに近接した部分に集中させているという重要な示唆を与え るものであろう (Brown ら、1993)。活性型のゼラチナーゼAは 悪性浸潤性細胞の浸潤先端に局在しているのが観察されている のはこの考えと一致している (Monsky ら、1993)。

\section{F-4. TIMPsによる活性調節}

MMPsはすべてTIMPsと呼ばれる強く結合するタンパク質 性阻害物質により阻害される (Stetler-Stevenson 1990)。現在3種 のヒトのTIMPsがクローニングされ、1次構造が決定されてい る。TIMP-1、2、および3の cDNA配列のデー夕を基にしたコア タンパク質の予想される分子量 $(\mathrm{MWs})$ はすべておおよそ21 kDa である。しかしながら、TIMP-1およびTIMP-3では糖鎖が付加す るため、SDS-PAGEにおいてはそれぞれ $28 \mathrm{kDa}$ と $24 \mathrm{kDa}$ のタン パク質として泳動される (Wilde ら、1994)。TIMP-2 は糖鎖が付 加されず、そのMWは21-24 kDaであると報告されている (Stetler - Stevenson ら、1989)。すべてのTIMPsはあらゆる活性型の MMPs と高い親和力で非共有結合によって複合体を形成する。 これらの複合体は化学量論的には1：1である。さらに、TIMP-1 


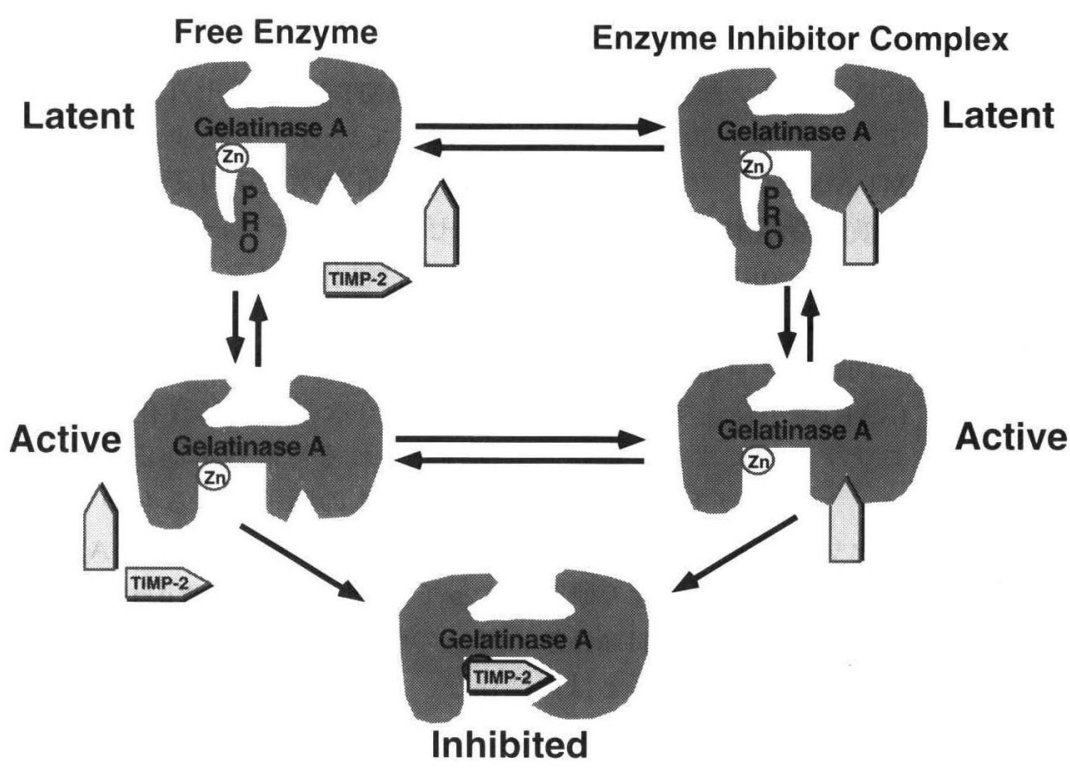

Fig. 3. Potential interactions between progelatinase $A$ and TIMP-2. Potential in vitro interactions between progelatinase $A$ and TIMP are illustrated in the top half of this diagram. Progelatinase A posses a single, unique carboxy terminal binding site for TIMP- 2 . Through this site progelatinase can bind the carboxy terminal domain of TIMP-2 to form a proenzyme-inhibitor complex. This proenzyme inhibitor complex (upper right hand corner) lacks gelatinolytic activity but retains matrix metalloproteinase inhibitory activity. This complex can apparently be activated by organomercurials in vitro or by MT-MMP at the cell surface. Following activation of the progelatinase $\mathrm{A}$ the catalytic site becomes accessible. This catalytic site can interact with either TIMP-1 or TIMP-2. However, if TIMP-2 is already bound to the carboxy terminus of the progelatinase A it can preclude TIMP-1 from interacting with the active site. Interaction of TIMP-1 or TIMP-2 with the catalytic site results in inhibition of proteolytic activity. plexes are formed between specific TIMPs and pro-gelatinases: TIMP- 1 with progelatinase $\mathrm{B}$, and TIMP-2 with progelatinase A. This is thought to allow tight regulation of the activation of these enzymes. Progelatinase A will bind to TIMP-2, but not TIMP-1, while activated gelatinase A binds both TIMP-1 and TIMP-2.

All three TIMPs have 12 conserved cysteine residues which form 6 disulfide bonds. The disulfide bonding pattern has been determined for TIMP-1 (Williamson et al., 1990) and is thought to be the same for the other TIMPs (DeClerck et al., 1993). These bonds divide the TIMP molecule into two distinct domains. Evidence from studies involving truncated enzymes and cross-linking methods, suggests the following model: the $\mathrm{N}$-terminal domain of TIMPs is inhibitory, while the C-terminal domain confers binding specificity. So while the N-terminal domain of TIMPs -1 and -2 bind to the $\mathrm{N}$-terminal domain of active gelatinase A, only the C-terminal domain of TIMP-2 will bind specifically to the C-terminal domain of progelatinase A (Fig. 3). As evidence to support this model, C-terminally truncated forms of progelatinase A will not bind TIMP-2, but activated $\mathrm{C}$-terminally truncated gelatinase $\mathrm{A}$ is inhibited by TIMP-2 (Fridman et al., 1992; Murphy et al., 1992; Nguyen et al., 1994; Willenbrock et al., 1993). In addition, crosslinked progelatinase A-TIMP-2 complex can still be activated and show gelatinase activity, which suggests that the TIMP-2 is not bound to the active site (Kleiner et al., 1992). It has also been found that the latent progelatinase A-TIMP-2 complex is capable of binding activated gelatinase B, to form a ternary complex devoid of gelatinase activity (Curry et al., 1992; Kolkenbrock et al., 1991). This evidence suggests that when TIMP-2 is complexed to progelatinase A, the inhibitory N-terminal domain of TIMP-2 is available for interaction with gelatinase B. The inhibition of active MMPs by TIMP-1 and
はゼラチナーゼBとそしてTIMP-2はゼラチナーゼAというよう に、特異的なTIMPsとプロゼラチナーゼとの間に複合体が形成 される。このことからこれら酵素の活性化は厳密に調節されて いるのだと考えられている。活性化されたゼラチナーゼAが TIMP-1 とTIMP-2の双方に結合するのに対し、プロゼラチナーゼ AはTIMP-2に対し結合するがTIMP-1とは結合しない。

3つのすべてのTIMPsは 12個の同じ位置に存在するシステ イン残基を持ち、これらは6つのジスルフィド結合を形成する。 ジスルフィド結合の様式はTIMP-1において決定され(Williamson ら、1990)、それはほかのTIMPsでも同様であると考えられてい る(DeClerck ら、1993)。これらの結合により、TIMP分子は2つ の異なった領域に分けられる。欠損醭素や組換え実験の研究か ら得られた結果から、次のモデルが推測される：TIMPsのC末端 領域が結合の特異性を与えるのに対し、N末端領域は阻害に寄 与する。よってTIMPs-1および2のN末端領域は活性型ゼラチ ナーゼAのN末端領域に結合するのに対し、TIMP-2のC末端領域 のみが特異的にプロゼラチナーゼAのC末端領域に結合する。(3 図) このモデルを支持する証拠としては、プロゼラチナーゼA のC末端領域を欠損したものはTIMP-2 と結合しないが、活性化 されたC末端欠損ゼラチナーゼAはTIMP-2によって阻害される (Fridman ら、1992; Murphy ら、1992 ; Nguyen ら、1994; Willenbrock ら、1993)。さらに、結合したプロゼラチナーゼATIMP-2複合体は、まだ活性化させることができ、活性化される とゼラチナーゼ活性を示す。このことからTIMP-2は活性部位に 結合していないことを示している (Kleinerら、1992)。また、潜 在型プロゼラチナーゼA-TIMP-2複合体は活性化されたゼラチ ナーゼBと結合し、ゼラチナーゼ活性の全くない3量体を形成す ることが見いだされている(Curryら、1992; Kolkenbrock ら、 1991)。この結果はTIMP-2がプロゼラチナーゼAと結合しても TIMP-2のN末端にある阻害領域がゼラチナーゼBとの結合に使 
TIMP-2 is significantly decreased by removal of the C-terminal domain of the TIMP molecule. By deletion mutagenesis, it has been shown that interactions between the $\mathrm{C}$-terminal domains of TIMPs and MMPs influence the rate of complex formation. Ionic interactions involving the negatively charged $\mathrm{C}$-terminus of TIMP-2, are thought to be important in the rapid binding to the C-terminus of pro-gelatinase A (Willenbrock et al., 1993). In summary, much progress has recently been made in explaining the interactions between TIMPs and the gelatinases. However, it remains to be seen whether the two TIMP domains interact with the two gelatinase binding sites simultaneously, or whether the TIMP molecule can only interact with one binding site at a time.

The fact that TIMPs bind to latent gelatinases, suggests that the TIMPs may have a functions in addition to the inhibition of enzyme activity. Consistent with this hypothesis, the findings of Kleiner et al., (1993) suggest that gelatinase ATIMP-2 complex formation may protect the enzyme from autodegradation. These investigators found that recombinant gelatinase A began to show low molecular weight cleavage products almost immediately after activation with pAPMA, while activated complex showed no breakdown products for at least $24 \mathrm{~h}$. If autodegradation of gelatinase A were only dependent on its own level of enzyme activity, then breakdown products should have been seen within $2 \mathrm{~h}$, based on specific activities of free and complexed enzyme. Complex formation with TIMP-2 may therefore inhibit autodegradation of gelatinase A, independent of its inhibitory effect on type-IV collagen degradation. The authors (Kleiner et al., 1993) put forward the hypothesis that there may be two distinct modes of gelatinase $\mathrm{A}$ action: i) secretion of free enzyme leads to high specific activity and a short half-life, and ii) secretion of complex leads to a low specific activity and a long half-life. As examples of these two situations, cultured synovial cells appear to secrete free gelatinase A (Okada et al., 1990), and cultured human melanoma cells secrete progelatinase A-TIMP-2 complex (StetlerStevenson et al., 1989).

Evidence that gelatinase A inhibition by TIMP-2 is an important factor in physiological and pathological processes, has come from studies on angiogenesis (Schnaper et al., 1993) and tumor cell adhesion (Ray and Stetler-Stevenson 1995). In studies where endothelial cells were cultured on Matrigel, Schnaper and coworkers (Schnaper et al., 1993) found that the formation of tube networks was increased by addition of recombinant gelatinase $\mathrm{A}$, and decreased both by neutralizing antibody and TIMP-2. While tube network formation was decreased by gelatinase A concentrations above a critical level, this decrease was reversed by addition of exogenous TIMP-2. These results suggest that while gelatinase A activity has an important role in angiogenesis, excessive levels of activity will inhibit the process. Ray and Stetler-Stevenson (Ray and
われ得ることを示している。TIMP分子のC末端領域を切除する とTIMP-1 と TIMP-2による活性型MMPsの阻害が有意に減少す る。欠損変異体生成から、TIMPs と MMPsのC末端領域の間の結 合が複合体形成の速度に対し影響を及ぼすことが見いだされて いる。負に荷電しているTIMP-2のC末端領域などのイオン的相 互作用が、プロゼラチナーゼAのC末端領域と素早く結合するた めには重要であると考えられている(Willenbrockら、1993)。全 体的には、最近TIMPsとゼラチナーゼの間の相互作用の解明が 非常に進んだが、TIMPの2つの領域がゼラチナーゼの2つの結合 部位と同時に相互作用するのかどうか、それともTIMP分子は一 度に1つの結合部位としか相互作用できないのかはいまだはっき りしていない。

TIMPsが潜在型ゼラチナーゼと結合するという事実は、 TIMPsが酵素活性を阻害する以上の機能を持つかもしれないと いうことを示している。ゼラチナーゼA-TIMP-2複合体の形成は 酵素の自己分解から保護しているのかもしれないというKleiner らの知見 (1993) は、この仮説とよく一致する。これらの研究者 たちは組換え体ゼラチナーゼAはpAPMAによる活性化の直後か ら低分子量の分解生成物ができ始めるのに活性化された複合体 では、少なくとも24時間以内では分解生成物ができないという ことを見いだしている。もしゼラチナーゼAの自己分解がそれ 自身の酵素活性の程度のみによるのであるのならば、遊離の酵 素と複合体形成している酵素の比活性から、分解生成物が 2 時 間以内に見られるはずである。そ枕え TIMP-2との複合体形成 の意味は、IV型コラーゲン分解に扔ける阻害効果とは別にゼラ チナーゼAの自己分解の阻害にあるのかもしれない。著者ら (Kleiner ら、1993) はゼラチナーゼAの作用には2つの区別される 様式があるという仮説を推奨している: i) 遊離の酵素の分泌は高 い比活性と短い半減期を誘導する。ii) 複合体の分泌は低い比活 性と長い半減期を誘導する。これら2つの様式の例としては、培 養滑膜細胞は遊離のゼラチナーゼAを分泌しているし(Okadaら、 1990)、培養メラノーマ細胞ではプロゼラチナーゼA-TIMP-2複 合体を分泌している (Stetler-Stevenson ら、1989)。

TIMP-2によるゼラチナーゼAの阻害が生理的および病理的 過程において重要な因子であるという証拠が血管新生 (Schnaper ら、1993) と腫瘍細胞の接着 (Ray と Stetler-Stevenson 1995) の研 究から得られた。Schnaperとその協同研究者らは血管内皮細胞 をマトリゲル上に培養した時に、ネットワークの形成が組換え 体のゼラチナーゼAの添加により促進され、中和抗体やTIMP-2 どちらによっても減少することを見いだした (Schnaperら、 1993)。ところがゼラチナーゼA濃度がある濃度を越えると、 ネットワーク形成が減少するが、この減少は外からTIMP-2を添 加することにより回復する。これらの結果は、ゼラチナーゼA の活性が血管新生に重要な役割を果たしている一方で、活性が 強すぎるとその過程を阻害するということを示している。Ray と Stetler-Stevenson (Ray と Stetler-Stevenson、1995)は、A2058ヒ 
Stetler-Stevenson, 1995) found that adhesion of A2058 human melanoma cells to the tissue culture substrate was decreased by treatment of cells with exogenous gelatinase A, but increased by inhibiting the endogenous enzyme with either neutralizing antibody or TIMP-2. These results suggest that cell adhesion is markedly influenced by local levels of gelatinase A activity. According to the "three-step" hypothesis, key events in the process of tumor invasion are tumor cell adhesion to extracellular matrix (ECM) structures, ECM degradation by proteolysis, and then tumor cell migration into the degraded area. While proteolysis is required for tumor invasion, these results suggest that excessive proteolysis may inhibit this process: excessive proteolysis would impair tumor cell adhesion, so disrupting the cell-matrix interactions required for migration and invasion. It may therefore be necessary for the level of proteolytic activity to fall within a certain critical range, in order for both tumor invasion and angiogenesis to occur. Precise regulation of the balance between gelatinase A and TIMP-2 expression is therefore likely to be essential.

\section{G. Gelatinase A Expression in Normal Tissues}

Studies on the expression of gelatinase A in normal tissues has provided evidence that this enzyme plays important roles in the processes of growth, development and involution. Gelatinase A is the most widely expressed of the MMPs studied so far. In human embryonic tissues, cytoplasmic immunostaining for the enzyme can be detected in cells derived from all three embryonic layers (Casasco et al., 1995). In adult tissues, gelatinase $\mathrm{A}$ has been identified in keratinocytes, skin fibroblasts, chondrocytes, osteoblasts, endothelial cells, monocytes, and a number of other cell types (Birkedal-Hansen et al., 1993). From in situ hybridization studies, the mRNA generally appears to be restricted to cells of mesenchymal origin and is not seen in epithelial cells in vivo (Matrisian 1994; Reponen et al., 1992).

Comparison of progelatinase A expression with other MMPs by in situ hybridization reveals major differences. Stromelysin-3 mRNA is also expressed in connective tissues, but has a much more restricted distribution (Basset et al., 1990). Matrilysin mRNA by contrast, is expressed in epithelia rather than connective tissues, and has been detected in glandular epithelium of mouse small intestine and human endometrium (Rodgers et al., 1993). While studies on a variety of cultured fibroblast and epithelial cell types show gelatinase B expression, in situ hybridization studies indicate that in developing mouse embryos, gelatinase B mRNA is largely restricted to osteoclasts and bone marrow cells (Reponen et al., 1994). This suggests that in vivo, gelatinase B expression is very much more limited than gelatinase A expression.

Dramatic changes in MMP expression are seen in human endometrium during the menstrual cycle (Rodgers et al.,
トメラノーマ細胞の組織培養基質に対する接着が外因性ゼラチ ナーゼAの処理により減少するが、内因性酵素を中和抗体か TIMP-2で阻害することによって増加することを見いだした。こ れらの結果から、細胞接着がゼラチナーゼA活性の局在量に よって著しく影響を受けることが推測される。「3段階」仮説に よれば、腫瘍の浸潤における重要な段階として、細胞外マ卜 リックス $(\mathrm{ECM})$ 構造への腫瘍細胞の接着、タンパク質分解によ るECMの破壊、そして破壊領域への腫瘍細胞の移動がある。夕 ンパク質分解は腫瘍の浸潤に必須であるが、これらの結果とし ての過剩なタンパク質分解はこの過程を阻害するかもしれない: 過剩なタンパク質分解は腫瘍細胞の接着を減らし、そのために 移動と浸潤に必要とされる細胞 - マトリックス相互作用が破壤 されるだろう。それゆえにタンパク質分解活性のレベルはある 臨界範囲以内に落ち着くことが腫瘍の浸潤や血管新生が起こる ためには必要なのであろう。ゼラチナーゼAとTIMP-2の発現の バランスの精密な調節はそれゆえに欠くことのできないもので あろう。

\section{G. 正常組織でのゼラチナーゼAの発現}

正常組織におけるゼラチナーゼAの発現の研究から、この 酵素が成長や発生、退縮の過程に重要な役割を果たしていると いう証拠が得られている。ゼラチナーゼAは研究されている限 りにおいて、もっとも広く発現されているMMPsである。ヒ卜 の胚の組織についての、酵素の細胞質免疫染色では3つの肧葉す べてに由来する細胞で検出することができた (Casasco ら、1995) 。成人の組織では、ゼラチナーゼAは皮膚角質細胞、皮膚線維 芽細胞、軟骨細胞、骨芽細胞、内皮細胞、単球、その他多くの 細胞において同定されている (Brikedal - Hansen ら、1993)。in situハイブリダイゼーションの研究から、その mRNAは一般的に 中胚葉起源の細胞に限定してみられ、in vivoにおいて上皮細胞 には検出されない (Matrisian 1994 ; Reponen ら、1992)。

In situハイブリダイゼーションにより他のMMPsとゼラチ ナーゼAの発現を比較してみると、大きな違いが明らかとな る。ストロメライシン -3 mRNAもまた結合組織で発現している が、限られた分布でしかない (Basset ら、1990)。マトリライシ ンmRNAは対照的に、結合組織よりはむしろ上皮に発現してお り、マウスの小腸腺上皮や、ヒト子宮内膜で検出された (Rodgers ら、1993)。様々な培養線維芽細胞や上皮細胞での研究 で、ゼラチナーゼBの発現が検出されているのに対し、発生中の マウスの肧についてのin situハイブリダイゼーションの研究では ゼラチナーゼB mRNAは破骨細胞と骨髄細胞に広く限定されて いた (Reponen ら、1994)。このことはin vivoでは、ゼラチナー ゼBの発現はゼラチナーゼAの発現に比べて非常に限られている ということを示している。

MMP発現の劇的な变化は、性周期における子宮内膜におい てみられる (Rodgers ら、1994)。周期の終わりに向かって、ゼ 
1994). Towards the end of the cycle, gelatinases A and B, interstitial collagenase, stromelysins 1,2 , and 3 , and matrilysin are all expressed, suggesting a concerted effort by MMPs to breakdown and release menstrual endometrium. By contrast, none of the MMPs show detectable expression in the secretory phase of the cycle, except for gelatinase A which is detected throughout the cycle. The variation in MMP expression through the menstrual cycle may be due to regulation by progesterone, which is present at increased levels during the secretory phase (Rodgers et al., 1994). The fact that gelatinase A production changes relatively little throughout the cycle, is further evidence of the constitutive nature of gelatinase A expression.

\section{H. Gelatinase A Expression in Human Tumors}

Evidence that gelatinase $\mathrm{A}$ is required for tumor invasion and metastasis has come from a number of experimental studies correlating enzyme activity with tumor aggressiveness (Liotta et al., 1980; Nakajima et al., 1989; Nakajima et al., 1987; Turpeenniemi-Hujanen et al., 1985). Immunocytochemical and in situ hybridization studies have shown increased gelatinase A expression in a variety of human tumors, including carcinomas of the colon (Newell et al., 1994; Poulsom et al., 1992), breast (Polette et al., 1994; Soini et al., 1994), prostate (Boag and Young 1994; Stearns and Wang 1993), and ovary (Autio-Harmainen et al., 1993; Campo et al., 1992). The fact that basement membrane disruption is a characteristic feature of carcinomas (Barsky et al., 1983) provides circumstantial evidence that proteolytic targeting of basement membrane components like type IV collagen is critical for the invasive behavior of malignant tumor cells. It seems likely that these breaks are necessary to allow the invasion and spread of tumor cells, and that gelatinase $\mathrm{A}$ is at least partly responsible for their development.

For carcinomas of the colon, breast, and ovary, in situ hybridization studies show that gelatinase A mRNA can only be detected in the connective tissue stroma of these tumors. However, gelatinase A protein is detected mainly in the neoplastic epithelium of these tumors by immunocytochemistry (Autio-Harmainen et al., 1993; Levy et al., 1991; Monteagudo et al., 1990; Polette et al., 1994). It may be worth noting that no discrepancy was seen between immunocytochemical and in situ hybridization results for prostate cancer or lung cancer, where both protein and mRNA were mainly detected in the neoplastic epithelium (Boag and Young 1994; Urbanski et al., 1992). One explanation for the discrepancy between immunocytochemical and in situ hybridization results for cancers of colon, breast and ovary, could be that the half-life of the gelatinase A mRNA, and /or the efficiency of translation, differs between the stromal cells and neoplastic epithelial cells. Another explanation is that the enzyme is synthesized predominantly in the tumor stroma, but that on secretion it is mostly
ラチナーゼAそしてB、間質コラゲナーゼ、ストロメライシン 1、 2、そして3、マトリライシンのすべてが発現されており、MMPs が子宮内皮の破壊や遊離に協調して働いていることを物語って いる。対照的に、分泌期においては、周期をとおして検出され るゼラチナーゼAを除いて全くMMPsの発現は検出されない。性 周期をとおしてのMMPの発現の多様性は、分泌期において存在 量が増加するプロゲステロンによって調節されていると考えら れている (Rodgers ら、1994)。ゼラチナーゼAの産生は性周期を とおしてほとんど変化しないということは、ゼラチナーゼAの 発現が恒常的であるのが自然であるという更なる証拠となって いる。

\section{H. ヒト腫瘍におけるゼラチナーゼAの発現}

ゼラチナーゼAが腫瘍の浸潤と転移に必要とされる証拠 は、酵素活性と腫瘍の浸潤性に関連する数多くの実験研究から 得られている (Liotta ら、1980; Nakajima ら、1989; Nakajima ら、 1987 ; Turpeenniemi-Hujanen ら、1985)。免疫細胞化学とin situ ハイブリダイゼーションによって、結腸癌 (Newell ら、1994； Poulsom 5、1992)、肺癌 (Polette ら、1994; Soini ら、1994)、前 立腺癌 (Boag と Young 1994 ; Stearns と Wang 1993)、卵巣癌 (Autio-Harmainen ら、1993; Campo ら、1992)などのヒトの腫瘍 において、ゼラチナーゼAの発現の増加が示された。基底膜の 破壊が悪性腫瘍の特徵的な性質であるという事実 (Barsky ら、 1983) は、IV型コラーゲンのような基底膜のタンパク質成分を分 解することが悪性腫瘍細胞が浸潤するために不可欠であること の状況証拠となっている。このような破壊が腫瘍細胞の浸潤や 転移を成し遂げるのに必要であり、ゼラチナーゼAは少なくと もそれらの進展の一部に寄与しているようだ。

結腸癌、肺癌、卵巣癌についてのin situハイブリダイゼー ションを用いた研究では、ゼラチナーゼA mRNAはこれら腫瘍 の結合組織基質にのみ検出された。しかしながら、ゼラチナー ゼAタンパク質は免疫細胞化学的にみるとおもにこれら腫瘍の 腫瘍上皮中に検出された (Autio-Harmainen ら、1993; Levy ら、 1991 ; Monteagudo ら、1990；Poiette ら、1994)。前立腺癌や肺癌 ではタンパク質とmRNAがどちらもおもに腫瘍上皮中に検出さ れ、免疫細胞化学的方法とin situハイブリダイゼーションで不一 致が見られなかったことは全く価值がないのかもしれない (Boag と Young 1994 ; Urbanski ら、1992)。結腸癌、乳癌、卵巣癌で得 られた免疫細胞化学的方法とin situハイブリダイゼーションの結 果が一致しなかったことに関する1つの説明としては、ゼラチ ナーゼA mRNAの半減期と、もしくは翻訳段階の効率が組織基 質細胞と腫瘍上皮細胞では異なっているのではないかというも のがある。そのほかの説明としては、酵素は腫瘍基質では主に 合成されているが、分泌の段階において腫瘍上皮細胞表面の受 
bound by receptors on the surface of neoplastic epithelial cells. For MT-MMP expression in human cancer, the results of in situ hybridization studies are conflicting, with one report that expression is entirely stromal for carcinomas of colon, breast and head and neck (Okada et al., 1995), while other studies on gastric carcinoma suggest that expression is mainly in the neoplastic epithelium (Nomura et al., 1995). Based on immunocytochemical studies, MT-MMP protein is mainly localized to neoplastic epithelial cells in lung cancer (Sato et al., 1994) and gastric cancer (Nomura et al., 1995), and this is consistent with the model that gelatinase A is activated on the surface of invading tumor cells.

A number of studies have suggested that the level of gelatinase A expression in human cancers may correlate with the stage and aggressiveness of the tumor, and may therefore provide useful prognostic information. For example, Garbisa and coworkers (Garbisa et al., 1992) found that in lung cancer patients, serum levels of gelatinase A were significantly higher when distant metastases were present, and also when there was a failure to respond to chemotherapy. In addition, Grigioni and coworkers (Grigioni et al., 1991) found that increased immunostaining for gelatinase $\mathrm{A}$ in hepatocellular carcinomas was associated with poorer survival. Increased immunostaining of breast cancer tissue has also been correlated with a higher frequency of local recurrence (Daidone et al., 1991). While this evidence is encouraging, the level of active enzyme will probably be more informative, as it is the activated enzyme that contributes directly to the invasive phenotype. Quantitative gelatin zymography has so far been used in a small number of studies to assess the level of active gelatinase A in tumors. In non-small cell lung cancer a correlation has been reported between increased gelatinase A activation and the extent of tumor spread (Brown et al., 1993). In breast cancer, the proportion of gelatinase $\mathrm{A}$ in the active form has been found to increase with higher tumor grade (Davies et al., 1993), although one other group found no correlation with staging or other existing prognostic markers (Brown et al., 1993). In colon cancer, increased levels of both active and proenzyme forms of gelatinase A were detected in neoplastic cells microdissected from invasive areas, as compared with an equal number of normal epithelial cells (Emmert-Buck et al., 1994). Further studies may show that zymography can provide valuable prognostic information in cancer patients. However, the success of these studies will depend on careful sampling of tumors, so that samples are mainly composed of viable neoplastic cells.

\section{Conclusion}

Gelatinase A expression is regulated by numerous factors and at many levels. These observations provide strong evidence that this member of the MMP family has important and possibly unique functions. This is confirmed by the fact that it
容体にほとんどが結合してしまったというものがある。ヒトの 癌についてMT-MMPの発現をin situハイブリダイゼーションで 調べた研究の結果は、もっぱらその発現は結腸癌、乳癌、頭、 および澒部の癌の基質であったという1つの報告 (Okada ら、 1995)があり、一方では胃癌についての研究ではその発現はおも に腫瘍上皮に見られた (Nomura ら、1995) というものがあり混 乱している。免疫細胞化学的研究によると、MT-MMP夕ンパク 質は肺癌 (Sato ら、1994) と胃癌 (Nomura ら、1995)ではおもに 腫瘍上皮細胞に局在しており、これはゼラチナーゼAが浸潤腫 瘍細胞の表面で活性化されるというモデルと一致している。

数多くの研究が、ヒト癌におけるゼラチナーゼAの発現の 程度が、腫瘍の段階や浸潤性と関係していて、それゆえに予後 についての有益な情報をもたらしてくれるだろうことを示して いる。例えば、Garbisaとその協同研究者らは (Garbisa ら、1992) 肺癌患者で遠隔転移がある場合、そしてまた化学療法に失敗し た場合、ゼラチナーゼAの血清中量が有意に高いことをみいだ した。さらに、Grigioniとその協同研究者らは (Grigioni ら、 1991) 肝細胞癌において生存率が低くなるに従いゼラチナーゼA に対する免疫染色性が増加することを見いだしている。乳癌組 織に拈ける免疫染色性の増加はまた、局所的再発の頻度の高ま りと相関関係にあった (Daidone ら、1991)。この結果は重要で あるが、浸潤という表現型に直接寄与するのは活性化された酵 素であるので活性酵素の量がわかれば、多分もっといろいろな 情報を与えてくれるであろう。これまで腫瘍の活性ゼラチナー ゼAの量を評価するのに定量的なゼラチンザイモグラフィーを 用いた研究が行われてきた。非小細胞肺癌ではゼラチナーゼ $\mathrm{A}$ の活性化の増加と癌の転移の間の相関が報告されている(Brown ら、1993)。乳癌ではゼラチナーゼAの活性型の比率が癌の進行 が高まるほど増加していることが見いだされたが (Davis ら、 1993)、他のグループは癌の進行度もしくはほかの予後について の指標との相関は見いだしていない (Brownら、1993)。結腸癌 においては、浸潤領域から採取した腫瘍上皮細胞では、同数の 正常上皮細胞と比べてゼラチナーゼAの活性型と前駆体双方の 量が増加しているのが検出された (Emmert-Buck ら、1994)。更 に研究が進めばザイモグラフィーにより癌患者の予後について の有益な情報をうることができるだろう。しかし、これら研究 の成功のためにはおもに生きた腫瘍上皮細胞からなるサンプル を腫瘍から注意深く採取することが必要である。

\section{I. 結 論}

ゼラチナーゼAの発現は非常に多くの数の因子や数多くの 段階で調節されている。これらの観察からMMPファミリーにお いてゼラチナーゼAが重要で、しかもユニークな機能を持つに 違いないということが強く示された。このことは多くの組織で 
is constitutively expressed and widely distributed in many tissues. Gelatinase A expression is also regulated in a very different manner from other MMPs, suggesting that it may play a key role in cell : matrix interactions. Unlike other MMPs, the principle step in regulation of progelatinase A activity is conversion from latent to active enzyme. The identification of MTMMP as the molecule responsible for the cell surface activation of progelatinase $\mathrm{A}$, has provided a promising new target for therapeutic intervention in those invasive and degenerative diseases in which gelatinase A has been implicated.
ゼラチナーゼAが構成的に発現され広く分布しているという事 実により確証される。ゼラチナーゼAの発現はまた、他のMMPs と非常に異なった方法で調節されており、そのことは細胞とマ トリックスの相互作用において重要な役割を果たしていること を推測させる。他のMMPsと異なり、プロゼラチナーゼA活性の 調節における主要な段階は潜在型から活性型への变換である。 プロゼラチナーゼAの細胞表面での活性化に寄与する分子とし てのMT-MMPが見いだされたので、ゼラチナーゼAの関わって いる浸潤性、そして変性を伴う疾患についてMT-MMPが治療上 の新しい標的となるに違いない。

東京工業大学・生命理工学部・糖鎖生命科学

中島 英規 訳

\section{References}

Atkinson, S.J., Ward, R.V., Reynolds, J.J., and Murphy, G. (1992) Biochem. J. 288, 605-611

Autio-Harmainen, H., Karttunen, T., Hurskainen, T., Hoyhtya, M., Kauppila, A., and Tryggvason, K. (1993) Lab. Invest. 69, 312-321

Barsky, S.H., Siegal, G.P., Jannotta, F., and Liotta, L.A. (1983) Lab. Invest. 49, 140-147

Basset P, Bellocq J.P.,Wolf, C., Stoll, I., Hutin, P., Limacher, J.M., Podhajcer, O.L., Chenard, M.P., Rio, M.C., and Chambon, P. (1990) Nature 348, 699-704

Bergmann, U., Tuuttila, A., Stetler-Stevenson, W.G., and Tryggvason, K. (1995) Biochemistry 34, 2819-2825

Birkedal-Hansen, H., Moore, W.G., Bodden, M.K., Windsor, L.J., Birkedal-Hansen, B., DeCarlo, A., and Engler, J.A. (1993) Crit. Rev. Oral Biol. Med. 4, 4197-4250

Boag, A.H., and Young, I.D. (1994) Am. J. Pathol. 144, 585-591

Brown, P.D., Bloxidge, R.E., Anderson, E., and Howell, A. (1993) Clin. Exp. Metastasis. 11, 183-189

Brown, P.D., Bloxidge, R.E., Stuart, N.S., Gatter, K.C., and Carmichael, J. (1993) J. Natl. Cancer Inst. 85, 574-578

Brown, P.D., Kleiner, D.E., Unsworth, E.J., and Stetler-Stevenson, W.G. (1993) Kidney Int. 43, 163-170

Brown, P.D., Levy, A.T., Margulies, I.M., Liotta, L.A., and Stetler-Stevenson, W.G. (1990) Cancer Res. 50, 6184-6191

Campo, E., Merino, M.J., Tavassoli, F.A., Charonis,A.S., Stetler-Stevenson, W.G., and Liotta, L.A. (1992) Am J Surg Pathol. 16, 500-507

Cao, J., Sato, H., Takino, T., and Seiki, M. (1995) J. Biol. Chem. 270, 801-805

Casasco, A., Casasco, M., Reguzzoni, M., Calligaro, A., Tateo, S., Stetler-Stevenson, W.G., and Liotta, L.A. (1995) Eur. J. Histochem. 39, 3138

Collier, I.E., Wilhelm, S.M., Eisen, A.Z., Marmer, B.L., Grant, G.A., Seltzer, J.L., Kronberger, A., He, C.S., Bauer, E.A., and Goldberg, G.I. (1988) J. Biol. Chem. 263, 6579-6587

Curry,V.A., Clark, I.M., Bigg, H., and Cawston, T.E. (1992) Biochem. J. 285, 143-147

Daidone, M.G., Silvestrini, R., D’Errico, A., Di Fronzo, G., Benini, E., Mancini, A.M., Garbisa, S., Liotta, L.A., Grigioni, W.F. (1991) Int. J. Cancer 48, 529-532

Davies, B., Miles, D.W., Happerfield, L.C., Naylor, M.S., Bobrow, L.G., Rubens, R.D., and Balkwill, F.R. (1993) Br. J. Cancer 67, 1126-1131

DeClerck, Y.A., Yean, T.D., Lee, Y., Tomich, J.M., and Langley, K.E. (1993) Biochem. J. 289, 65-69

Delany, A.M., and Brinckerhoff, C.E. (1992) J. Cell Biochem. 50, 400-410

Emmert-Buck, M.R., Roth, M.J., Zhuang, Z., Campo, E., Rozhin, J., Sloane, B.F., Liotta, L.A., and Stetler-Stevenson, W.G. (1994) Am. J. Pathol. 145, 1285-1290

Emonard, H.P., Remacle, A.G., Noel, A.C., Grimaud, J.A., Stetler-Stevenson, W.G, and Foidart, J.M. (1992) Cancer Res. 52, 5845-5848

Fridman, R., Fuerst, T.R., Bird, R.E., Hoyhtya, M., Oelkuct, M., Kraus, S., Komarek, D., Liotta, L.A., Berman, M.L., and Stetler-Stevenson, W.G. (1992) J. Biol. Chem. 267, 15398-15405

Fridman, R., Toth, M., Pena, D., and Mobashery, S. (1995) Cancer Res. 55, 2548-2555.

Frisch, S.M., Reich, R., Collier, I.E., Genrich, L.T., Martin, G., and Goldberg, G.I. (1990) Oncogene 5, 75-83

Garbisa, S., Scagliotti, G., Masiero, L., Di Francesco, C., Caenazzo, C., Onisto, M., Micela, M., Stetler-Stevenson, W.G., and Liotta, L.A. (1992) Cancer Res. 52, 4548-4549

Grigioni, W.F., Garbisa, S., D’Errico, A., Baccarini, P., Stetler-Stevenson, W.G., Liotta, L.A., and Mancini, A.M. (1991) Am. J. Pathol. 138, 647-654

Huhtala P, Chow LT, Tryggvason K. (1990) J. Biol. Chem. 265, 11077-11082

Kerr, L.D., Miller, D.B., and Matrisian, L.M. (1990) Cell 61, 267-278

Keski-Oja, J., Lohi, J., Tuuttila, A., Tryggvason, K., and Vartio,T. (1992) Exp. Cell Res. 202, 471-476

Kleiner, D.E. Jr., and Stetler-Stevenson, W.G. (1993) Curr. Opin. Cell Biol. 5, 891-897

Kleiner, D.E. Jr., Tuuttila, A., Tryggvason, K., Stetler-Stevenson, W.G. (1993) Biochemistry 32, 1583-1592

Kleiner, D.E. Jr., Unsworth, E.J, Krutzsch, H.C., Stetler-Stevenson, W.G. (1992) Biochemistry 31, 1665-1672

Kolkenbrock, H., Orgel, D., Hecker-Kia, A., Noack, W., and Ulbrich, N. (1991) Eur. J. Biochem. 198, 775-781

Levy, A.T., Cioce, V., Sobel, M.E., Garbisa, S., Grigioni, W.F., Liotta, L.A., and Stetler-Stevenson, W.G. (1991) Cancer Res. 51, $439-444$

Liotta, L.A., Abe, S., Robey, P.G., and Martin, G.R. (1979) Proc. Natl. Acad. Sci. USA 76, 2268-2272 
Liotta, L.A., Tryggvason, K., Garbisa, S., Hart, I., Foltz, C.M., and Shafie, S. (1980) Nature 284, 67-68

Matrisian, L.M. (1994) Ann. N. Y. Acad. Sci. 6, 42-50

Monsky, W.L., Kelly, T., Lin, C.Y., Yeh, Y., Stetler-Stevenson, W.G., Mueller, S.C., and Chen, W.T.(1993) Cancer Res. 53, 3159-3164

Monteagudo, C., Merino, M.J., San-Juan, J., Liotta, L.A., and Stetler-Stevenson, W.G. (1990) Am. J. Pathol. 136, 585-592

Murphy, G., Nguyen, Q., Cockett, M.I., Atkinson, S.J., Allan, J.A., Knight, C.G., Willenbrock, F., and Docherty, A.J. (1994) J. Biol. Chem. 269, 6632-6636

Murphy, G., Willenbrock, F., Crabbe, T., O’Shea, M., Ward, R., Atkinson, S., O’Connell, J., and Docherty, A. (1994) Ann. N. Y. Acad. Sci. 732, 31-41

Murphy, G., Willenbrock, F., Ward, R.V., Cockett, M.I., Eaton, D., and Docherty, A.J. (1992) Biochem. J. 283, 637-641

Nakajima, M., Lotan, D., Baig, M.M., Carralero, R.M., Wood, W.R., Hendrix, M.J., and Lotan, R. (1989) Cancer Res. 49, 1698-1706

Nakajima, M., Welch, D.R., Belloni, P.N., and Nicolson, G.L. (1987) Cancer Res. 47, 4869-4876

Newell, K.J., Witty, J.P., Rodgers, W.H., and Matrisian LM. (1994) Mol. Carcinog. 10, 199-206

Nguyen, Q., Willenbrock, F., Cockett, M.I., O’Shea, M., Docherty, A.J., and Murphy G. (1994) Biochemistry 33, 2089-2095

Nomura, H., Sato, H., Seiki, M., Mai, M., and Okada, Y. (1995) Cancer Res. 55, 3263-3266

Okada, A., Bellocq, J.P., Rouyer, N., Chenard, M.P., Rio, M.C., Chambon, P., and Basset, P.(1995) Proc. Natl. Acad. Sci. USA 92, $2730-2734$

Overall, C.M. (1991) Trends Glycosci. Glycotech. 3, 384-399

Overall, C.M., and Sodek J. (1990) J. Biol. Chem. 265, 21141-21151

Overall, C.M., Wrana, J.L., and Sodek, J. (1991) J. Biol. Chem. 266, 14064-14071

Pei, D., and Weiss, S.J. (1995) Nature 375, 244-247

Polette, M., Gilbert, N., Stas, I., Nawrocki, B., Noel, A., Remacle, A., Stetler-Stevenson, W.G., Birembaut, P., and Foidart, M. (1994) Virchows Arch. 424, 641-645

Poulsom, R., Pignatelli, M., Stetler-Stevenson, W.G., Liotta, L.A., Wright, P.A., Jeffery, R.E., Longcroft, J.M., Rogers, L., and Stamp, G.W. (1992) Am. J. Pathol. 141, 389-396

Ray, J.M., and Stetler-Stevenson, W.G. (1994) Eur. Resp. J. 7, 2062-2072

Ray, J.M., and Stetler-Stevenson, W.G. (1995) EMBO J. 14, 908-917

Reponen, P., Sahlberg, C., Huhtala, P., Hurskainen,T., Thesleff, I., and Tryggvason, K. (1992) J. Biol. Chem. 267, 7856-7862

Reponen, P., Sahlberg, C., Munaut, C., Thesleff, I., and Tryggvason, K. (1994) Ann. N. Y. Acad. Sci. 732, 472-475

Rodgers,W.H., Matrisian, L.M., Giudice, L.C., Dsupin, B., Cannon, P., Svitek, C., Gorstein, F., and Osteen, K.G. (1994) J. Clin. Invest. 94, 946953

Rodgers,W.H., Osteen, K.G., Matrisian, L.M., Navre, M., Giudice, L.C., and Gorstein, F. (1993) Am. J. Obstet. Gynecol. 168, 253-260

Salo, T., Liotta, L.A., Keski-Oja, J., Turpeenniemi-Hujanen,T., and Tryggvason, K. (1982) Int. J. Cancer 30, 669-673

Salo, T., Liotta, L.A., and Tryggvason, K. (1983) J. Biol. Chem. 258, 3058-3063

Sato, H., Takino, T., Okada, Y., Cao, J., Shinagawa, A., Yamamoto, E., and Seiki, M. (1994) Nature 370, 61-65

Schnaper, H.W., Grant, D.S., Stetler-Stevenson, W.G, Fridman, R. D’Orazi, G., Murphy, A.N., Bird, R.E., Hoythya, M., Fuerst, T.R., French, D.L., and et al. (1993) J. Cell. Physiol. 156, 235-246

Seltzer, J.L., Eisen, A.Z., Bauer, E.A., Morris, N.P., Glanville, R.W., and Burgeson, R.E. (1989) J. Biol. Chem. 264, 3822-3826

Soini, Y., Hurskainen, T., Hoyhtya, M., Oikarinen, A., and Autio-Harmainen, H. (1994) J. Histochem. Cytochem. 42, $945-951$

Stearns, M.E., and Wang, M. (1993) Cancer Res. 53, 878-883

Stetler-Stevenson, W.G. (1990) Cancer Metastasis Rev. 9, 289-303

Stetler-Stevenson, W.G., Brown P.D., Onisto, M., Levy, A.T., and Liotta, L.A. (1990) J. Biol. Chem. 265, 13933-13938

Stetler-Stevenson, W.G., Krutzsch, H.C., and Liotta, L.A. (1989) J. Biol. Chem. 264, 17374-17378

Stetler-Stevenson, W.G., Krutzsch, H.C., Wacher, M.P., Margulies, I.M., and Liotta, L.A. (1989) J. Biol. Chem. 264, 1353-1356

Strongin, A.Y., Collier, I., Bannikov, G., Marmer, B.L., Grant, G.A., Goldberg, G.I. (1995) J. Biol. Chem. 270, $5331-5338$

Strongin, A.Y., Marmer, B.L., Grant, G.A., and Goldberg, G.I. (1993) J. Biol. Chem. 268, 14033-14039

Turpeenniemi-Hujanen, T., Thorgeirsson, U.P., Hart, I.R., Grant, S.S., and Liotta, L.A. (1985) J. Natl. Cancer Inst. 75, 99-103

Urbanski, S.J., Edwards, D.R., Maitland, A., Leco, K..J, Watson, A., and Kossakowska, A.E. (1992) Br. J. Cancer 66, $1188-1194$

Van Wart, H., and Birkedal-Hansen, H. (1990) Proc. Natl. Acad. Sci. USA. 87, 5578-5582

Ward, R.V., Atkinson, S.J., Slocombe, P.M., Docherty, A.J., Reynolds, J.J., and Murphy, G. (1991) Biochim. Biophys. Acta 1079, 242-246

Wilde, C.G., Hawkins, P.R., Coleman, R.T., Levine, W.B., Delegeane, A.M., Okamoto, P.M., Ito, L.Y., Scott, R.W., and Seilhamer, J.J. (1994) DNA Cell Biol. 13, 711-718

Willenbrock, F., Crabbe, T., Slocombe, P.M., Sutton, C.W., Docherty, A.J., Cockett, M.I., O’Shea, M., Brocklehurst, K., Phillips, I.R., and Murphy, G.(1993) Biochemistry 32, 4330-4333

Williamson, R.A., Marston, F.A., Angal, S., Koklitis, P., Panico,M., Morris, H.R., Carne, A.F., Smith, B.J., Harris, T.J., and Freedman, R.B. (1990) Biochem. J. 268, 267-274

Yu, M., Sato, H., Seik,i M., and Thompson, E.W. (1995) Cancer Res. 55, 3272-3277

Received on October 13, 1995, accepted on October 18,1995 